\title{
An Ethiopian Orthodox Monk in the Cradle of the Reformation: Abba Mika'el, Martin Luther, and the Unity of the Church
}

\author{
Stanislau Paulau
}

The 16th-century Protestant Reformation became a turning point not only for Latin Christendom. Rather, it profoundly impacted the trajectory of Christianity as a worldwide religion. Arguably, the ways in which the Reformation legacy has taken root and been expressed contextually around the worldparticularly in Africa, Asia, and Latin America-constitute one of the most vibrant research fields within the academic discipline of World Christianity. Yet, the relations between the Reformation and the wider world can also be conceptualized in a radically different way. Instead of looking at the Reformation as an initially European phenomenon that became global as a result of worldwide transmission and cross-cultural diffusion of its impulses (predominantly in the 19th and 2oth centuries), in the following I would like to invert this perspective and ask whether the Reformation itself can be seen as a product of the increasing global interconnectedness of the early modern world. ${ }^{1}$

The reformers were doubtlessly aware that the Christian world was comprised not only of Latin Christendom but also of various branches of Eastern Christianity, which extended geographically from Eastern Europe, through the Eastern Mediterranean (including Northeast Africa), to South and East Asia. The fact that these churches did not recognize the primacy of the pope became an important argument in the early anti-Roman polemics of the reformers. Thus, already at the Leipzig Debate in the summer of 1519 (but also in his later writings), Martin Luther expressed the opinion that the Eastern churches were

1 Cf. Stanislau Paulau, "Re-Envisioning Ecumenism and World Christianity in the Age of Reformation: The Theological Dialogue of Abba Mika'el and Martin Luther," Ecumenical Trends 50, no. 3 (2021): 2-5. In more detail this perspective is elaborated in Stanislau Paulau, Das andere Christentum. Zur transkonfessionellen Verflechtungsgeschichte von äthiopischer Orthodoxie und europäischem Protestantismus (Göttingen: Vandenhoeck \& Ruprecht, 2021). An open access version is available at: https://doi.org/10.13109/9783666336041. 
neither heretical nor schismatic, even though they did not recognize the primacy of the pope as divine right. ${ }^{2}$

Reformation historians have typically argued that Luther himself had no personal contact whatsoever with Eastern Christians; ${ }^{3}$ the commencement of Orthodox-Protestant ${ }^{4}$ interactions is usually associated either with the activities of Philipp Melanchthon in the $1540 \mathrm{~s}^{5}$ or else, more frequently, with the

2 At its most elaborated, this argument is expressed in Luther's work Von dem Papstthum zu Rom gegen den hochberühmten Romanisten zu Leipzig (On the Papacy in Rome: An Answer to the Celebrated Romanist at Leipzig), published in 1520. Martin Luther, D. Martin Luthers Werke. Kritische Gesamtausgabe. Vol. 6, Schriften 1519/20 (einschließlich Predigten, Disputationen) (Weimar: Hermann Böhlau, 1888), 285-324. Regarding the position of the Orthodox churches in Luther's ecclesiology, see: Fairy von Lilienfeld, "Zum Wesen der Kirche. Einheit, Kontinuität und Universalität der heiligen katholischen und apostolischen Kirche in der Theologie Martin Luthers und in der 'eucharistischen Ekklesiologie' des 20. Jahrhunderts," in Sophia-Die Weisheit Gottes. Gesammelte Aufsätze 1983-1995, ed. Karl Christian Felmy, Heinz Ohme and Karin Wildt (Erlangen: Lehrstuhl für Geschichte und Theologie des christlichen Ostens, 1997), 3-12. Cf. also George Pósfay, “'The Whole Christian Church on Earth'-Luther's Conception of the Universality of the Church," Lutheran Theological Seminary (Gettysburg) Bulletin 72 (1992): 20-43.

3 Hans-Dieter Döpmann formulated this view with reference to the international network of the Wittenberg reformer in the following way: "Many foreigners visited him [Luther], but no Orthodox." ("Viele Ausländer besuchten ihn [Luther], aber keine Orthodoxen.") Hans-Dieter Döpmann, "Das Verhältnis Luthers und der Lutheraner zu den orthodoxen Kirchen," Theologische Literaturzeitung 109, no. 5 (1984): 323 .

4 In this paper, the generic term "Orthodox churches" comprises both Eastern Orthodox and Oriental Orthodox (i.e., dyophysite and miaphysite) churches. The Ethiopian Orthodox Church belongs to the latter group.

5 Thus, for example, Daniel Benga suggests locating the first personal meeting between a Reformer and an Orthodox Christian in Melanchthon's meeting with the Greek Franciscus Magera at the Regensburg Reichstag in 1541. Daniel Benga, David Chytraeus (1530-1600) als Erforscher und Wiederentdecker der Ostkirchen. Seine Beziehungen zu orthodoxen Theologen, seine Erforschungen der Ostkirchen und seine ostkirchlichen Kenntnisse (Giessen: vvB Laufersweiler Verlag, 2012), 54. Cf. also Daniel Benga, "Philipp Melanchthon und der christliche Osten. Bis heute unbekannte Begegnungen Melanchthons aus den Jahren 1541 und 1556 mit orthodoxen Christen," Orthodoxes Forum 16 (2002): 19-38. For Franciscus Magera, see: Martin Hein, "Das Schicksal des Franz Magera. Ein Beitrag zum Verhältnis von Reformation und Türkenkriegen," Archiv für Reformationsgeschichte 73 (1982): 308-313. Dietmar Plajer, on the other hand, assumed that the first contacts between Reformation and Orthodox Christians can be traced back to the activities of the reformer of the Transylvanian-Saxon church Johannes Honterus (ca. 1498-1549) in Brașov (Kronstadt) in the 1540s. Dietmar Plajer, "Auftrag und Grenzen. Zu den Anfängen lutherisch-orthodoxer Beziehungen im 16. Jahrhundert," Review of Ecumenical Studies Sibiu 10, no. 1 (2018): 90-91. While it has been speculated whether a scholar from the University of Krakow who prepared a German-Romanian-Polish edition of the New Testament and visited Luther in 1532 might have been Orthodox, the source material, as the authors themselves admit, provides no evidence for such an assumption. Gunnar 
correspondence between the Tübingen theologians and Patriarch Jeremias II of Constantinople on the Augsburg Confession in the 1570s. ${ }^{6}$

And yet, this established narrative has to be reconsidered in the light of the new evidence showing that the first documented encounter of the Reformers with Eastern Christianity can be traced to the time of Luther. Remarkably, this encounter took place not due to European but to Orthodox initiative. In 1534,

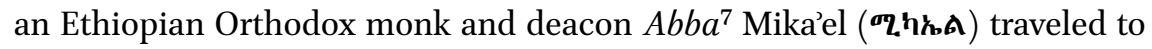
Wittenberg where he contacted the Wittenberg reformers, Martin Luther and Philipp Melanchthon. ${ }^{8}$ Arguably, this meeting should be regarded as the very

Hering, "Orthodoxie und Protestantismus," in Jahrbuch der Österreichischen Byzantinistik 31, no. 2, ed. Herbert Hunger (Wien: Verlag der Österreichischen Akademie der Wissenschaften, 1981), 827; Benga, David Chytraeus, 49-5o.

6 Dorothea Wendebourg, Reformation und Orthodoxie. Der ökumenische Briefwechsel zwischen der Leitung der Württembergischen Kirche und Patriarch Jeremias II. von Konstantinopel in den Jahren 1573-1581 (Göttingen: Vandenhoeck \& Ruprecht, 1986), 18-24; Benga, David Chytraeus, 45-50; Johannes Karmiris, "Luther und Melanchthon über die Orthodoxe Kirche (I)," Kyrios 6, no. 2 (1966): 77-104; Johannes Karmiris, "Luther und Melanchthon über die Orthodoxe Kirche (II)," Kyrios 6, no. 3 (1966): 150-173; Oskar Wagner, "Luther-Osteuropa und die griechisch-orthodoxe Kirche," Kyrios 4 (1964): 69-9o; Viorel Mehedintu, "Martin Luther und die Ostkirche," Ökumenische Rundschau 32 (1983): 291-309; Ernst Benz, "Die östliche Orthodoxie und das kirchliche Selbstbewußtsein der Reformation," in Evangelisches und orthodoxes Christentum in Begegnung und Auseinandersetzung, ed. Ernst Benz and Lev Zander (Hamburg: Agentur des Rauhen Hauses, 1952), 101-16o; Theodor Nikolaou, "Die orthodoxlutherischen Beziehungen im 16. Jahrhundert," Ökumenische Information 14/15 (1980): 7-10; Vasilică Mugurel Păvălucă, "Einige schriftliche Verweise Martin Luthers auf die Ostkirche," Review of Ecumenical Studies Sibiu 9, no. 3 (2017): 36o-370. For further genealogies of early relations between the Reformation and Eastern Christianity, all of which get along without Martin Luther, see for example: Ernst Benz, Wittenberg und Byzanz. Zur Begegnung und Auseinandersetzung der Reformation und der östlich-orthodoxen Kirche (München: Fink, 1971), 4-33; Paschalis Kitromilides, "Orthodoxy and the West. Reformation to Enlightenment," in The Cambridge History of Christianity. Vol. 5, Eastern Christianity, ed. Michael Angold (Cambridge: Cambridge University Press, 2006), 187-209; Gisa Bauer, "Evangelisch-orthodoxe Religionsgespräche im 16. Jahrhundert," in Zwischen theologischem Dissens und politischer Duldung. Religionsgespräche der Frühen Neuzeit, ed. Irene Dingel, Volker Leppin and Kathrin Paasch (Göttingen: Vandenhoeck \& Ruprecht, 2018), 43-6o.

$7 \quad A b b a$ ( $\bigwedge$, derived from $a b$, "father") is an honorific title applied in Ethiopian Orthodox tradition to monks and clergy and is frequently used as a prefix to their names.

8 For a detailed evaluation of this encounter, see: Paulau, Das andere Christentum, 21-31 and 42-72. Previously, Martin Brecht and Tom G.A. Hardt briefly mentioned the meeting of Martin Luther and Abba Mika'el, however they did not go into detail about it. Cf. Martin Brecht, Martin Luther. Vol. 3, Die Erhaltung der Kirche: 1532-1546 (Stuttgart: Calwer, 1987), 67; Tom G.A. Hardt, "The Confessional Principle. Church Fellowship in the Ancient and in the Lutheran Church," Logia. A Journal of Lutheran Theology viII, no. 2 (1999): 27. Most recently David Daniels drew attention to this encounter and emphasized its extraordinary importance for church historical studies: "I believe the dialogue between Luther and Michael the Deacon is historically significant. For historical studies, it might be on par with the colloquy between 
first significant Protestant-Orthodox encounter. However, it is not the mere fact of such an early encounter between an Ethiopian Orthodox monk and the German reformers that make it extraordinarily significant. Of high importance is rather its theological dimension. This intercultural dialogue about the core issues of the Christian doctrine resulted in a mutually shared conviction that Ethiopian Orthodox Christians and proponents of the Wittenberg Reformation belonged to the very same Church of Christ.

This contribution has a twofold objective. Firstly, it aims to reconstruct the circumstances and the main content of the theological dialogue between $\mathrm{Abba}$ Mika'el and the Wittenberg reformers. Secondly, the paper seeks to uncover the history of the subsequent oblivion of this early Protestant-Orthodox encounter.

An Exceptional Encounter: Abba Mika'el in Wittenberg

On 31 May 1534 Philipp Melanchthon wrote a letter to his friend, the Wittenberg lawyer Benedict Pauli, in order to inform him about an unexpected event that occurred earlier that day. ${ }^{9}$ According to Melanchthon, an Ethiopian monk came to Wittenberg and had a discussion with Luther. Despite initial communication difficulties-Melanchthon had to invite one of the fellow scholars as an interpreter-Abba Mika'el and Luther were able to speak about the doctrine of the Trinity. The African guest proved himself to be homo ingeniosus. ${ }^{10}$

But who was this Ethiopian monk and how did he come to Wittenberg? By the turn of the 16th century, Ethiopian Orthodox Christians were by no means rare guests in the Latin West. As supposed subjects of the legendary

Luther and Zwingli." David Daniels, "Luther and Ethiopian Christianity," in Reformation in the Context of World Christianity. Theological, Political and Social Interactions Between Africa, Asia, the Americas and Europe, ed. Frieder Ludwig et al. (Wiesbaden: Harrassowitz, 2019), 28.

$9 \quad$ Letter of Philipp Melanchthon to Benedict Pauli, 31.05.1534. Heinz Scheible, ed., Melanchthons Briefwechsel. Kritische und kommentierte Gesamtausgabe. Vol. T6, Texte 1395-1683 (1534-1535) (Stuttgart-Bad Cannstatt: frommann-holzboog, 2005), 99-10o. Cf. also Carolus Gottlieb Bretschneider, ed., Philippi Melanthonis Opera Quae Supersunt Omnia. Vol. 2 (Halis Saxonum: C.A. Schwetschke et filium, 1835), 730-731. See also the recent introduction and translation in: Timothy J. Wengert, "Melanchthon's First Letter about an Ethiopian Visitor to Luther's Wittenberg," Lutheran Quarterly 35 (2021): 182-188. For the view arguing that Melanchthon possibly refers in this letter to a different visitor, see: David Daniels III and Lawrence Anglin, "Luther and the Ethiopian Deacon," Lutheran Quarterly 32 (2018): 428-434.

10 Letter of Philipp Melanchthon to Benedict Pauli, 31.05.1534. Scheible, Melanchthons Briefwechsel. Vol. T6, 100. 
Prester John, a monarch who was believed to rule over a powerful Christian empire in the midst of Muslims and pagans, they were not only tolerated, but rather treated with great respect (at least in most of the cases). ${ }^{11}$ Having established a network of diasporic communities in the Mediterranean region-the most prominent ones could be found in Jerusalem, Cairo, Nicosia and RomeEthiopian Christians facilitated increasing circulation of knowledge between Northeast Africa and Latin Europe and widely engaged in interaction with Latin Christianity. ${ }^{12}$ Since, according to Melanchthon, Abba Mika'el was able to communicate in broken Italian (although he did not speak either Greek or Latin), ${ }^{13}$ it can be assumed that he spent a long time in an Italian-speaking environment. Most likely he belonged to the Ethiopian monastic community in Rome. The church of Santo Stefano dei Mori (or Santo Stefano degli Abissini), adjacent to St. Peter's, which had served as the main meeting place and guest house for Ethiopian pilgrims from the 1480s onwards; it developed into an important center of Ethiopian Orthodox intellectual life and also received the formal status of an Ethiopian Orthodox monastic community in $1515 .{ }^{14} \mathrm{~A}$ fur-

11 Cf. Samuel Asghedom, "Contributo dell'Ospizio di Santo Stefano degli Abissini agli Studi Etiopici in Europa," in IV Congresso Internazionale di Studi Etiopici (Roma, 10-15 April 1972). Vol. 1 (Roma: Accademia nazionale dei Lincei, 1974), 393. On the myth of Prester John (Lat. Pres[by]ter Iohannes) and its association with Ethiopia, see: Wilhelm Baum, Die Verwandlungen des Mythos vom Reich des Priesterkönigs Johannes. Rom, Byzanz und die Christen des Orients im Mittelalter (Klagenfurt: Kitab, 1999); Lew Gumilev, Searches for an Imaginary Kingdom. The Legend of the Kingdom of Prester John (Cambridge: Cambridge University Press, 1987); Gianfranco Fiaccadori, "Prester John," in EAe 4 (2010): 209-216.

12 For Ethiopian journeys to Europe in the 16th century and Ethiopian diasporic communities in the Mediterranean, see: James De Lorenzi, "Red Sea Travelers in Mediterranean Lands: Ethiopian Scholars and Early Modern Orientalism, ca. 1500-1668," in WorldBuilding and the Early Modern Imagination, ed. Allison B. Kavey (New York: Palgrave Macmillan, 2010), 173-200; Samatha Kelly, "Medieval Ethiopian Diasporas," in A Companion to Medieval Ethiopia and Eritrea, ed. Samatha Kelly (Leiden: Brill, 2020), 427441; Matteo Salvadore, The African Prester John and the Birth of Ethiopian-European Relations, 1402-1555 (London: Routledge, Taylor \& Francis Group, 2017); Matteo Salvadore, "The Ethiopian Age of Exploration: Prester John's Discovery of Europe, 1306-1458," Journal of World History 21, no. 4 (2011): 593-627; Gianfranco Fiaccadori, "Venezia, l'Etiopia e l'Europa," in "Nigra sum sed formosa." Sacro e bellezza dell'Etiopia cristiana (13 Marzo10 Maggio 2009), ed. Giuseppe Barbieri and Gianfranco Fiaccadori (Crocetta del Montello: Terra ferma, 2009), 27-48; Samantha Kelly and Denis Nosnitsin, "The Two Yohannəses of Santo Stefano degli Abissini, Rome: Reconstructing Biography and Cross-Cultural Encounter Through Manuscript Evidence," Manuscript Studies: AJournal of the Schoenberg Institute for Manuscript Studies 2, no. 2 (2017): 392-426.

13 Letter of Philipp Melanchthon to Benedict Pauli, 31.05.1534. Scheible, Melanchthons Briefwechsel. Vol. T6, 99-100.

14 Cf. Gianfranco Fiaccadori, "Santo Stefano dei Mori," in EAe 4 (2010): 528-532; Sebastian 
ther indication of this hypothesis is provided by the manuscript "Vat. et. 47" of the Biblioteca Apostolica Vaticana, which formerly belonged to the Ethiopian Orthodox monastery in Rome. ${ }^{15}$ On fol. $215^{\mathrm{r}}$, at the very end of this $15^{\text {th }}$ century manuscript, there is an addendum of a later date that identifies a certain Mika'el from the Ethiopian Orthodox monastery in Rome as the owner of this

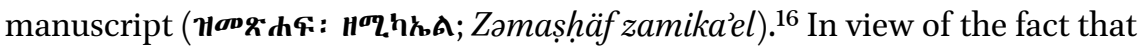
the entire monastic community was small even during its heyday between the $15^{20}$ and 155 os and consisted of around five to 40 monks (this number varied), ${ }^{17}$ it is quite conceivable that this Mika'el is identical with the Ethiopian deacon who visited Wittenberg.

Abba Mika'el stayed in Wittenberg until 4 July 1534. The two reformers were on site during almost the entire stay of $A b b a$ Mika'el and met repeatedly with him for theological discussions. ${ }^{18}$ Before the departure of the Ethiopian monk, the Wittenberg reformers issued him a formal letter of recommendation, that can be regarded as the key document of this encounter. The letter was drafted by Melanchthon and signed by Luther. Due to the importance of this document, it will be given in the following in both its original Latin version and an English translation:

Testimonium datum cuidam Aethiopi a d[omino] Mart[ino] Luth[ero]. $\Phi[$ i $\lambda \iota \pi \pi \circ \varsigma] \mathrm{M}[$ elanthon $] \mathrm{f}[$ ecit $]$.

Euringer, "San Stefano dei Mori (Vatikanstadt) in seiner Bedeutung für die abessinische Sprachwissenschaft und Missionsgeschichte," Oriens Christianus 32, no. 3 (1935): 38-59; Mauro da Leonessa, Santo Stefano Maggiore degli Abissini e le relazioni romano-etiopiche (Vatican: Tipografia Poliglota Vaticana, 1928); Marius Chaîne, "Un monastère éthiopien à Rome au xve et Xvie siècle," Mélanges de la Faculté Orientale, Bayreuth 5 (1911): 1-36; Sylvain Grébaut, "Contribution à l'histoire du couvent éthiopien San-Stefano-dei-Mori," Revue de l'Orient chrétien 26, no. 3 (1927): 211-218; Sylvain Grébaut, "La règle de Santo Stefano dei Mori," Revue de l'Orient chrétien 27, no. 3 (1929): 214-219.

15 Cf. Sylvain Grébaut and Eugène Tisserant, Bybliothecae apostolicae Vaticanae codices manu scripti recensiti iussu PiixI Pontificis maximi (Città del Vaticano: Byblioteca Vaticana, 1935), 199-201.

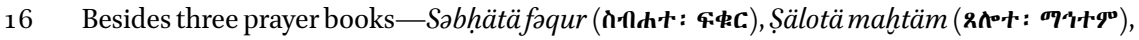

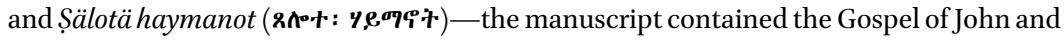
the Revelation of John.

17 Cf. Mauro da Leonessa, Santo Stefano, 185-188.

18 The only exception were the few days the reformers spent in Dessau from 3 to 8 June 1534. Cf. Martin Luther, D. Martin Luthers Werke. Kritische Gesamtausgabe. Vol. 59, Nachträge zu Band 1-57 und zu den Abteilungen "Deutsche Bibel" und "Tischreden" (Weimar: Hermann Böhlaus Nachfolger, 1983), 351 and Heinz Scheible, ed., Melanchthons Briefwechsel. Kritische und kommentierte Gesamtausgabe. Vol. 10, Orte A-Z und Itinerar (Stuttgart-Bad Cannstatt: frommann-holzboog, 1998), 426-427. 
Fuit nobiscum in Germania dominus Michael, Aethiops diaconus, cum quo de doctrina christiana familiariter colloquentes audivimus eum cum symbolo, quod habet ecclesia occidentalis, recte convenire nec de trinitate aliud sentire, quam quod sentit ecclesia occidentalis. Ideo, quantum nos quidem possumus, commendamus eum bonis viris. Nam etsi orientalis ecclesia habet aliquas dissimiles ceremonias, ipse quoque iudicat, quod dissimilitudo earum non tollat unitatem ecclesiae nec pugnet cum fide, quia Christi regnum est spiritualis iustitia cordis, timor dei et per Christum fiducia. Hanc sententiam et nos probamus. Comperimus etiam ex eo, quod ritus, quem nos observamus in usu coenae domini et missa, convenit cum orientali ecclesia. Optamus autem, ut omnes gentes agnoscant et glorificent Christum et ei obediant vera fiducia misericordiae ipsius et dilectione proximi. Ideo rogamus bonos viros, ut christianam dilectionem et huic hospiti praestare velint. Witeb[ergae] 1534, 4. Non[as] Iulii.

MARTINUS LUTHERUS ${ }^{19}$

A letter of recommendation given to an Ethiopian by Mister Martin Luther. $\Phi$ i $\lambda$ i $\pi \pi \circ \varsigma$ Melanthon drafted it.

Mister Michael, an Ethiopian deacon, was with us in Germany. We spoke with him about the Christian doctrine on friendly terms and heard him rightly agree with the creed that the Western church holds. Nor does he think about the Trinity any differently than what the Western church thinks. Therefore, as much as we can, we recommend him to good people. For although the Eastern church observes some divergent ceremonies, he judges that this difference does not undermine the unity of the Church nor conflict with faith, because the Kingdom of Christ is spiritual righteousness of heart, fear of God, and trust through Christ. We, too, approve of this opinion. We also learned from him that the rite, which we observe at the Lord's Supper and the Mass, is in accord with the Eastern church. Moreover, we desire that all peoples acknowledge and glorify Christ and obey him through true trust in his mercy and through love of the neighbor. Therefore, we entreat good people that they, too, would show Christian love to this visitor. Wittenberg, July 4, 1534.

MARTIN LUTHER ${ }^{20}$

19 The text of the letter of recommendation is given according to the critical edition of Melanchthon's correspondence: Scheible, Melanchthons Briefwechsel. Vol. T6, 123-124.

20 Translation-s.P. For another recent English translation, see: David Daniels III and Lawrence Anglin, "Luther and the Ethiopian Deacon," Lutheran Quarterly 32 (2018): 428-434. 
The very fact that the Ethiopian monk had a letter of recommendation drawn up suggests that he sought further contacts with the representatives of the Reformation. And in fact, another letter from Melanchthon indicates that Abba Mika'el also intended to travel to France. It seems that on his way, the Ethiopian monk wanted to meet the Strasbourg reformer Martin Bucer (14911551). ${ }^{21}$ It is, however, not known whether these plans could be carried out or not.

\section{Key Themes of the Theological Dialogue between Abba Mika'el and} Martin Luther

\subsection{Trinity}

Based on the available sources we can determine that the main themes of the dialogue between $A b b a$ Mika'el and Martin Luther were among others the doctrines of the Trinity and the Lord's Supper. ${ }^{22}$ Since both sides had to deal with cultural and religious otherness, not only genuine theological convictions but also mutual misconceptions inevitably influenced the discussion and contributed to the perceived accord in faith. Therefore, the following analysis aims at disentangling these layers of the theological dialogue.

Already during the first encounter on Sunday, 31 May 1534, Martin Luther and Abba Mika'el have discussed the doctrine of the Trinity. ${ }^{23}$ But why of all topics, have they chosen exactly this one for the first conversation? Decisive for this choice could have been the fact that according to the Western Christian liturgical calendar the Trinity Sunday was celebrated on this day. Thus, immediately before meeting the Ethiopian monk, Luther had given a sermon in the Castle church of Wittenberg on the Trinity. In his sermon he tried to illustrate the doctrine of the Trinity of God using Jesus' conversation with Nicodemus from the Gospel of John (John 3:2-11). ${ }^{24}$

21 Cf. letter of Philipp Melanchthon to Martin Bucer, 04.07.1534, in which he recommends Abba Mika'el travelling to France: "[S.D. Fuit hic nobiscum Aethiops homo cupidus cognoscend(i).] s.D. Hic hospes mirabili studio tenetur cognoscendi varias nationes. Fuit itaque nobiscum et, cum familiariter multa de relligione et doctrina christiana collocuti essemus, visus est non abhorrere a studio pietatis. Ideo dedi hoc epistolium roganti et commendo eum tibi, mi Bucere, commendandum etiam aliis fratribus. Videre cupit Galliam. Melanthon." Scheible, Melanchthons Briefwechsel. Vol. T6, 122.

22 The two other broadly defined fields dealt with were ecclesiology and eschatology. For more details, see: Paulau, Das andere Christentum, 52-65.

23 Cf. Scheible, Melanchthons Briefwechsel. Vol. T6, 99-100.

24 Both Luther's sermon on Trinity Sunday (31 May 1534) and his sermon on the Monday after Trinity Sunday (1 June 1534) have been handed down. Martin Luther, D. Martin Luthers 
Moreover, at that time triadology also played an important role in Luther's thought due to another reason. Since the late 1520 s, when Luther became aware of the emergence of anti-Trinitarian teachings within the Reformation movement, he was confronted with the question of the scriptural conformity of the doctrine of the Trinity. ${ }^{25}$ In this context, the neo-Cappadocian triadology (which Luther, however, received in its form shaped by Latin authors) acquired an eminent importance for his theology. ${ }^{26}$ Owing to the fundamental nature of this issue, Luther repeatedly returned to it again in the early 1530s, trying to defend the Trinitarian theology of the early church as it was formulated at the first two ecumenical councils, the Council of Nicea (325) and the Council of Constantinople (381). ${ }^{27}$ Against this background, it does not seem all too surprising that Luther directed his initial conversation with the Ethiopian monk to the doctrine of the Trinity.

Werke. Kritische Gesamtausgabe. Vol. 37, Predigten der Jahre 1533 und 1534 (Weimar: Hermann Böhlaus Nachfolger, 1910), 414-424.

25 Cf. Reiner Jansen, Studien zu Luthers Trinitätslehre (Bern: Lang, 1976), 91-97.

26 On the importance of the patristic doctrine of the Trinity for Luther's theology, see: Christoph Markschies, "Luther und die altkirchliche Trinitätstheologie," in Luther-zwischen den Zeiten. Eine Jenar Ringvorlesung, ed. Christoph Markschies and Michael Trowitzsch (Tübingen: Mohr Siebeck, 1999); Jouko Martikainen, "Christologische und trinitätstheologische Aporien der östlichen Kirche aus der Sicht Luthers," in Luther und die trinitarische Tradition: Ökumenische und philosophische Perspektiven, ed. Joachim Heubach (Erlangen: Martin-Luther-Verlag, 1994). Luther oriented himself to early church models even in his dissociation from misguided developments in the Trinitarian theology. Thus he writes in the testamentary confession of faith, which concludes his work Vom Abendmahl Christi, Bekenntnis: "Erstlich gleube ich von hertzen den hohen artickel der goettlichen maiestet / das Vater / son / heiliger geist drey Unterschiedliche personen / ein rechter / einiger / natuerlicher / warhafftiger Gott ist / schepffer hymels vnd der erden / aller dinge widder die Arrianer / Macedonier / Sabelliner / vnd der gleichen ketzerey." Martin Luther, D. Martin Luthers Werke. Kritische Gesamtausgabe. Vol. 26, Vorlesung über 1. Timotheus 1528; Schriften 1528 (Weimar: Hermann Böhlaus Nachfolger, 1909), 50o. In his sermon on the Feast of the Trinity on 23 May 1535-exactly one year after his encounter with Abba Mika'el — Luther even stated that in the Trinitarian dogma "God speaks about himself" ("Gott also von sich selbst redet"). Martin Luther, D. Martin Luthers Werke. Kritische Gesamtausgabe. Vol. 41, Predigten der Jahre 1535 und 1536 (Weimar: Hermann Böhlaus Nachfolger, 1910), 270. Philipp Melanchthon, too, saw himself as a representative of the neo-Cappadocian Trinitarian theology and in his polemic against the anti-Trinitarians he expressly referred to the teaching of the Cappadocian Church Fathers. Cf. Ashley H. Hall, Philip Melanchthon and the Cappadocians. A Reception of Greek Patristic Sources in the Sixteenth Century (Göttingen: Vandenhoeck \& Ruprecht, 2014), 122-128.

27 Ibid., 149-206. See also: Ulrich Asendorf, Die Theologie Luthers nach seinen Predigten (Göttingen: Vandenhoeck \& Ruprecht, 1988), 29-46. 
It is unclear whether Luther was familiar with the Legatio magni Indorum imperatoris Presbyteri Ioannis and the Legatio David Æthiopiae Regis, widely circulated collections of letters sent by Ethiopian rulers to the Portuguese monarchs and Roman pontiffs, which were by that time available in several Latin and German editions. ${ }^{28}$ Should this be the case, the remarkable triadological statements of Emperor Ləbnä Dəngəl, with which he began his letters to the Portuguese monarchs, may have prompted Luther to ask his guest about the Ethiopian Orthodox doctrine of the Trinity. ${ }^{29}$

According to Melanchthon, Abba Mika'el testified to Martin Luther that both Eastern and Western churches adhere to the same triadological teaching, "[...] concerning the Trinity he [Abba Mika'el] told Luther that the teaching of the Eastern church agreed with that of the Western church."30 This sentence reveals that in the view of the reformers the Ethiopian monk did not represent the Ethiopian Church, a particular Christian tradition with its own cultural, liturgical and dogmatic characteristics, but rather the "Eastern church" (orientalis ecclesia"). Precisely this undifferentiated attitude towards the Christian Orient (that was quite understandable due to the lack of information) made genuine understanding difficult.

The idea that Eastern and Western Christianity adhere to an identical doctrine of the Trinity was important for the Wittenberg reformers to such an extent, that they highlighted it in the recommendation for Abba Mika'el. ${ }^{31}$ However, upon closer inspection this conviction seems to be questionable.

First of all, it seems that the whole filioque (Latin: "and from the Son") controversy around the procession of the Holy Spirit was completely unknown to

28 Thus only in 1533-apart from numerous additional Latin editions and two Italian translations-appeared two German editions of the Legatio David Æthiopiae Regis: Bottschafft des groszmechtigsten Konigs David aus dem grossen und hohen Morenland den man gemeinlich nennet Priester Johann an Babst Clemens den siebenden zu Bononia vorhort in offnem consistorio am XXIX. Tag Januarii Anno M.D.XXXIII (Dresden: Wolfgang Stöckel, 1533) and Bottschafft des groszmechtigsten Konigs David aus dem grossen und hohen Morenland den man gemeinlich nennet Priester Johann an Babst Clemens den siebenden zu Bononia vorhort in offnem consistorio am XXIX. Tag Januarii Anno M.D.XXXIII (Nürnberg: Friedrich Peypus, 1533).

29 See for example the beginning of the letter of Ləbnä Dəngəl to Manuel I from 1521. Damião de Góis, Legatio magni Indorum Imperatoris Presbyteri Ioannis, ad Emanuelem Lusitaniae Regem, Anno Domini. M.D. XIII. (Antwerpen: Grapheus, 1532), 15-16. Remarkable in this regard is also the beginning of the letter of Ləbnä Dəngəl to João III. from 1524, where he artistically paraphrases the Creed of Nicea-Constantinople. Ibid., 32-33.

30 "[...] de Trinitate dixit [Abba Mika’el] Luthero sententiam orientalis ecclesiae convenientem cum occidentali ecclesia." Letter of Philipp Melanchthon to Benedict Pauli, 31.05.1534. Scheible, Melanchthons Briefwechsel. Vol. T6, 99-100. Translation-S.P. 
the conversers. On one side, the Wittenberg reformers taught with great selfevidence that the Holy Spirit proceeds from the Father and the Son. ${ }^{32}$ They did not only use the Niceno-Constantinopolitan Creed with the addition of the filioque, but were also convinced of the authenticity of the Pseudo-Athanasian Creed that originally contained the filioque. ${ }^{33}$ Since Martin Luther and Philipp Melanchthon had received the neo-Cappadocian triadology through the writings of the Latin authors, they were probably unacquainted with the fact that the original version of the Niceno-Constantinopolitan Creed still in use in Eastern and Oriental churches did not contain the filioque. On the other side, the Ethiopian monk seems to be unaware that the filioque was an integral part of the triadology in Latin Christianity.

Yet there is also another reason to doubt the declared agreement in the doctrine of the Trinity between the Wittenberg Reformation and Ethiopian Christianity. This reason has to do with the far-reaching church reforms, that had been carried out by Ethiopian Emperor Zära Ya'əqob (1399-1468) in the 15th century. These reforms aimed at unifying church doctrine and liturgical practice also influenced the triadology of the Ethiopian Orthodox Church. ${ }^{34}$

The decisive factor for this was the controversial discussion about the appropriate interpretation of biblical statements about the image of God, ${ }^{35}$ and, accordingly, of the theological concept of Mälks (aDAhd, "image"), in relation to the Trinity. ${ }^{36}$ Zära Ya'əqob tended towards a literal, even physical, interpretation of the biblical passages referring to the image of God. Based upon numerous biblical anthropomorphisms, he advocated the idea that the humanlike features can be ascribed to God. ${ }^{37}$ The image of the human being, which

32 Cf. Jansen, Studien, 98-99.

33 Bernd Oberdorfer, Filioque. Geschichte und Theologie eines ökumenischen Problems (Göttingen: Vandenhoeck \& Ruprecht, 2001), 266.

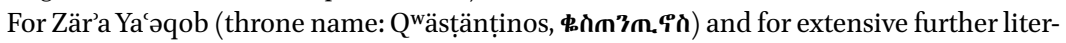
ature, see: Steven Kaplan and Marie-Laure Derat, "Zär’a Ya`əqob," in EAe 5 (2014): 146-150. Cf. Gen 1,27 .

36 For the prehistory and context of this debate, see: Getatchew Haile, "Religious Controversies and the Growth of Ethiopic Literature in the Fourteenth and Fifteenth Centuries," Oriens Christianus 65 (1981): 127-129; Kurt Wendt, "Die theologischen Auseinandersetzungen in der äthiopischen Kirche zur Zeit der Reformen des Xv. Jahrhunderts," in Atti del Convegno Internazionale di Studi Etiopici (Roma 2-4 Aprile 1959) (Roma: Accad. nazionale dei Lincei, 196o), 137-146; Pierluigi Piovanelli, "Les controverses théologiques sous le roi Zar’a Yā'əqob (1434-1468) et la mise en place du monophysisme éthiopien," in La controverse religieuse et ses formes, ed. Alain Le Boulluec (Paris: Cerf, 1995), 189-228.

37 Getatchew Haile, "The Homily of Zär'a Ya`əqob in Honour of St. John the Evangelist, EMML 148o, ff. 48 ${ }^{\mathrm{r}}$ 52 $^{\mathrm{v}}$," Oriens Christianus 67 (1983), 15o. Cf. Heyer, Die Kirche Äthiopiens, $255^{-256 .}$ 
took shape with Adam, was at the same time the image of God. A group of clergymen, who became known as the Zämika'elites, engaged in a theological discussion with the emperor. ${ }^{38}$ Following the patristic tradition, they argued that the similarity of the image of God and the image of man refers exclusively to the spiritual realm and that consequently one should not speak of a physical body of the invisible and boundless God. ${ }^{39}$

However, the Zämika'elites were declared heretics and the ideas of Zär'a Ya'əqob were integrated into the Ethiopian triadology ${ }^{40}$ The emperor attributed the physical characteristics that appeared at the creation of Adam and the incarnation of Christ to all three persons of the Trinity. According to him, the image of God was "in the Father and in the Son and in the Holy Spirit, be it the head or the face, the eyes or the ears or the nose, the lips or the teeth, be it the tongue or the hands and fingers, be it the heart according to the image or the feet and toes." ${ }^{41}$ Thus, in the middle of the 15th century the Zär'a Ya'əqob's

38 They were named after one of the leading theologians within this movement called

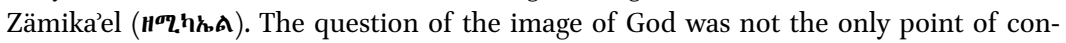
tention between them and Zära Ya'əqob. They also opposed for instance his eschatological millenarianism, the introduction of new Mariological feasts and the expansion of the biblical canon (these were the books of Enoch, Jubilees and the Testamentum Domini). For a brief introduction, see: Getatchew Haile, "Zämika'elites," in EAe 5 (2014): 131-133.

39 Cf. for instance: "God has no form like the form of man. God did not create in his image and likeness the form of Adam's body which is palpable and visible. The image of God and his likeness are an invisible spirit which was breathed upon Adam's face." Quoted in: Getatchew Haile, "Zämika'elites," 132. Or: "God is invisible and has no image which man may know; He alone knows His image." Getatchew Haile, "The Homily," 159. The most important work attributed to Zämika’elites is Fəkkare Mäläkot (G'h6: aDnh+; "Interpretations of Divinity"). Cf. Enrico Cerulli, Scritti teologici etiopici dei secoli XVI-XVII. Vol. 1, Tre opuscoli dei Mikaeliti (Città del Vaticano: Bibl. Apostolica Vaticana, 1958). The book both reflects on the image of God and argues against a literal interpretation of the anthropomorphic descriptions of God in the Bible. Cf. Pierluigi Piovanelli, "Connaissance de Dieu et sagesse humaine en Éthiopie. Le traité Explication de la Divinité attribué aux hérétiques 'mikaélites,'” Muséon 117 (2004): 193-227; Carlo Conti Rossini and Lanfranco Ricci, ed., Il Libro della Luce del Negus Zar'a Yā'qob (Mașhafa Berhān). Vol. 2 (Louvain: Peeters, 1965); Getatchew Haile, "The Homily," 149 (text) and 159 (translation).

40 Zär’a Ya'əqob accused them of teaching that "God had no form, and man is not formed after God's image." Getatchew Haile, "The Homily," 164. Apart from the rejection of the physical aspect in the Trinity, the following statement was attributed to Zämika'elites (which, however, is not found in their writings): "The Father, the Son and the Holy Spirit were three names, one person, one hypostasis and one aspect." Tedros Abraha, "Trinity," in EAe 4 (2010): 992. They were also accused of using a different version of the Trisagion in their services: "Holy, holy, holy God who is not likened to the image of creatures." Cf. Getatchew Haile, "Zämika’elites," 132; Conti Rossini and Ricci, Il Libro della Luce, 126 (text), 172 (translation).

Kurt Wendt, ed., Das Mașhafa Milād (Liber Nativitatis) und Maṣhafa Sellāsēe (Liber Trini- 
triadology, which was summarized in the concise formula "The Father in the perfect image of man," became the official teaching of the Ethiopian Church. ${ }^{42}$

Consequently, the declared agreement in the doctrine of Trinity was deluding for two reasons. On the one hand, there was a dissimilarity between Eastern and Western Christianity concerning the issue of the filioque. On the other hand, the Ethiopian triadology after the reforms of Zär’a Ya'əqob differed not only from the Trinitarian doctrine of Western Christianity, but also from that of the rest of the Christian East. While Zär'a Ya‘zqob's triadology remained unknown in the West until the 2oth century and thus could not be identified as a theological problem, the explosive nature of the filioque question became clear to both German Protestants and Orthodox Ethiopians already a few decades after the encounter of Abba Mika'el and Martin Luther. The Ethiopian Orthodox Christians were confronted with it in the course of the dispute with the Portuguese Jesuits in the $155 \mathrm{Os}^{43}$ the Lutherans were referred to the filioque as a serious point of difference in the course of the correspondence with Patriarch Jeremias II of Constantinople in the $1570{ }^{44}$

\subsection{Lord's Supper}

Another topic touched upon by Abba Mika'el and the Wittenberg reformers concerned sacramental theology, especially the understanding of the Lord's Supper. In the age of the Reformation, the question about the meaning and nature of the Eucharist was a matter of particularly intense theological dispute. It did not only mark a significant point of difference between Protestant and Roman Catholic theologians, but also caused a deep division within the Reformation movement itself.

tatis) des Kaisers Zar'a Yā'qob, [Vol. Versio 1] (Louvain: Peeters, 1963), 79-8o. Cf. Heyer, Die Kirche Äthiopiens, $255^{-256 .}$

Conti Rossini and Ricci, Il Libro della Luce, 128-129. Cf. Getatchew Haile, "Ethiopian Orthodox (Täwahədo) Church. History from Ancient Times till the Second Half of the 19th Century," in EAe 2 (2005), 417. The influence of Zär'a Ya'əqob's doctrine of the Trinity on the later Ethiopian theology needs a thorough examination. On the one hand, it shaped the iconography of the Trinity, which was now predominantly represented as three older men (cf. Marilyn E. Heldman, "Trinity in Art," in EAe 4 (2010): 994-996), on the other hand, the hymnography of the Ethiopian Orthodox Church firmly rejects the idea of the humanity of God. The liturgical texts rather pass on a classical triadology, i.e. that which the emperor regarded as heretical. Cf. Mebratu Kiros Gebru, Liturgical Cosmology. The Theological and Sacramental Dimensions of Creation in the Ethiopian Liturgy (Ph.D. Dissertation, University of Toronto, 2012), 40-44.

43 Leonardo Cohen, The Missionary Strategies of the Jesuits in Ethiopia (1555-1632) (Wiesbaden: Harrassowitz, 2009), 133-136.

44 Wendebourg, Reformation und Orthodoxie, 63-65. 
In the letter of recommendation, there is the following remarkable reference to the Eucharist: "We also learned from him [Abba Mika'el] that the rite, which we observe at the Lord's Supper and the Mass, is in accord with the Eastern church." ${ }^{55}$ Whereas the doctrine of the Trinity was discussed referring to the teaching of the Western and the Eastern churches in a rather general manner (without making any distinction between Roman Catholics and Protestants or between Ethiopian Christians and adherents of other Orthodox churches), the information about the mode of celebrating the Lord's Supper obtained from Abba Mika'el was unambiguously linked to the rite practiced by Luther and his followers. This emphasis was aimed at providing additional legitimization to the position held by Luther in the context of theological controversy over the Lord's Supper. The issue was of current interest. As late as on 10 March 1534, just before the meeting with the Ethiopian monk, he wrote a commentary on his own treaties Von der Winkelmesse und der Pfaffenweihe published the year before. There he polemicized sharply both against "the Papists," whose theology of the Mass sacrifice and private masses he vehemently rejected, and against "enemies of sacraments" within the Reformation camp, who denied the real presence of Christ in the Eucharist. ${ }^{46}$

Most likely, the aforementioned conformity of liturgical practices of the Ethiopian Orthodox Christians and the followers of Luther have referred to the features that differentiated them from the Catholic Christians, on one side, and the Zwinglians and the Anabaptists, on the other side. Both Ethiopian Orthodox Christians and followers of Luther supported the doctrine of the real presence of Christ in the Eucharist (in contrast to the Zwinglians and the Anabaptists) and distributed the Eucharist to the faithful under two forms and did not celebrate private masses (in contrast to the Roman Catholics). ${ }^{47}$ Ulti-

45 "Comperimus etiam ex eo, quod ritus, quem nos observamus in usu coenae domini et missa, convenit cum orientali ecclesia." Scheible, Melanchthons Briefwechsel. Vol. T6, 123124. Translation-S.P.

46 It should be emphasized that Luther was still involved in the Lord's Supper controversy at the time. As late as 10 March 1534, just before the meeting with the Ethiopian monk, he wrote a commentary on his own writing Von der Winkelmesse und der Pfaffenweihe published the year before. There he polemicized sharply both against "the Papists," whose theology of the Mass sacrifice and private masses he vehemently rejected, and against "enemies or sacraments" in the Reformation camp, who denied the real presence. Martin Luther, D. Martin Luthers Werke. Kritische Gesamtausgabe. Vol. 38, Schriften 1533/36 (Weimar: Hermann Böhlaus Nachfolger, 1912), 171-255 and 257-271.

47 Since Șägga Zä’ab, another Ethiopian theologian who visited Europa in the early 16 th century, in his work written for the Western readership mentions especially these characteristics of the Ethiopian liturgy, it is likely that $A b b a$ Mika'el also referred to them. Cf. Damião de Góis, Fides, Religio, Moresque Aethiopum: sub imperio Preciosi Johannis degen- 
mately, the assertion of supposed conformity with Ethiopian Orthodox liturgical practices was intended to serve both as a means of self-reassurance and as an argument in polemics against the theological adversaries. Such strategy of argumentation was applicable in so far as Luther's opponents in the Lord's Supper controversy-both Protestant and Roman Catholic-also sought to support their position with the help of references to the practice of the early church or quotations from the Church Fathers. ${ }^{48}$ The testimony of Abba Mika'el about the absence of private mass in Ethiopia seemed to verify the assessment of Luther, who saw this liturgical practice as a deviation from the tradition of the early church introduced in the Latin West by Pope Gregory I. The importance of this idea for the Wittenberg reformers can be exemplified by the fact that even three years after the encounter with $A b b a$ Mika'el, Philipp Melanchthon and Martin Luther referred to him in their conversation about the private mass, recorded in one of the "table talks":

Priuata missa multos sanctos decepit a tempore Gregorij, ober 8oo Jar. Et Ioannes Huss adhuc in illius superstition fuit captus. Miror, inquit Marti-

tium una cum enarratione confoederationis ac amicitiae inter ipsos Aethiopum imperatores et reges Lusitaniae initae [...] (Lovanii: Ex officina Rutgeri Rescij, 1540), 76-78; Siegbert Uhlig and Gernot Bühring, ed., Damian de Góis'Schrift über Glaube und Sitten der Äthiopier (Wiesbaden: Harrassowitz, 1994), 254-256.

48 For the use of quotations from the Church Fathers in the Lord's Supper controversy, see: Gottfried Hoffmann, Kirchenväterzitate in der Abendmahlskontroverse zwischen Oekolampad, Zwingli, Luther und Melanchton:Legitimationsstrategien in der inner-reformatorischen Auseinandersetzung um das Herrenmahl (Göttingen: Edition Ruprecht, 2011); Hall, Philip Melanchthon, 169-178. Already in the Apologie der Confessio Augustana (first published in 1531; officially declared a confessional document in 1537), written under the leadership of Melanchthon—but under the influence of Martin Luther-Article 10, the Lord's Supper article in Apology, referred to the epiclesis of consecration of the Greek Orthodox liturgy as proof of the doctrine of real presence. Irene Dingel, ed., Die Bekenntnisschriften der Evangelisch-Lutherischen Kirche. Vollständige Neuedition (Göttingen: Vandenhoeck \& Ruprecht, 2014), 242. Furthermore, in contrast to the medieval Latin practice of distributing the sacrament in only one form of bread, Article 22 refers to the Orthodox practice of distributing the sacrament in both forms. Dingel, Bekenntnisschriften, 581. Article 24, referring to the Greek Church, rejects the practice of private masses: "Das wir aber nicht privatmessen, sondern alleine eine öffentliche Mess, wenn das volck mit Communicirt, halten, das ist nichts widder die gemein Christliche kirchen. Denn inn der Kriechischen kirchen werden [bis] auff diesen tag kein Privatmessen gehalten, sondern allein ein Messe, und dasselbige auff die Sontage und hohe feste; das ist alles ein anzeigung des alten brauchs der kirchen." Dingel, Bekenntnisschriften, 616. Cf. also: Reinhard Slenczka, "Melanchthon und die orthodoxe Kirche des Ostens," in Philipp Melanchthon. Ein Wegbereiter für die Ökumene, ed. Jörg Haustein (Göttingen: Vandenhoeck \& Ruprecht, 1997), $115^{-116 .}$ 
nus Lutherus, quomodo Deus me ab hac una idolatria eripuerit. Respondit Philippus Melanthon, Aethiopem quendam ante triennium Witebergae fuisse, qui affirmasset in Asia nullum exemplum privatae missae esse, sed tantum unam publicam missam.

'The private mass deceived many saints from the time of Gregory, for over 800 years. Even John Hus was still captive to this superstition. I am amazed,' said Luther, 'how God wrested me from this singular idolatry.' Philip Melanthon responded: 'There was a certain Ethiopian who was here in Wittenberg three years ago. He affirmed that in Asia there were no instances of private masses but only the public mass. 49

The understanding of the Lord's Supper and the way of its performance by Ethiopian Orthodox Christians and Luther's followers indeed had some substantial resemblances. Yet, a detailed conversation about the actual rite of the Ethiopian Orthodox liturgy (\$⿳⺈, Q Q would obviously also manifest significant points of dissent. ${ }^{50}$ However, Luther's and Melanchthon's engagement into the inner-European eucharistic controversy inclined them to highlight the identified similarities and did not allow to use the conversation with $A b b a$ Mika'el in order to deepen the understanding of unique features of Ethiopian Christianity and its liturgical tradition.

\subsection{The One Church of Christ}

Undoubtedly the most important result of the proto-ecumenical dialogue between Abba Mika'el and Martin Luther was the conviction that the adherents of Ethiopian Orthodox Christianity and of the Wittenberg Reformation belonged to the same Church of Christ. The basis for this conviction was agreement on such central issues of the Christian teaching as the doctrine of the Trinity and the understanding of the Lord's Supper. The existing differences in some ceremonies were not regarded as essential and, consequently, were seen as adiaphora. This fundamental conviction was reflected in the already quoted letter of recommendation that the Wittenberg reformers issued to the Ethiopian monk before his departure from Wittenberg. Interestingly enough, the preserved formula that expresses this attitude is that of to Abba Mika'el: "Even though the Eastern church observes some divergent ceremonies, he [= Abba Mika'el] also judges that this difference does not abolish the unity of the

49 Luther, Tischreden. Vol. 5, 450-451. Translation-S.P.

50 For an introduction and further bibliography, see: Emmanuel Fritsch, "Qəddase," in EAe 4 (2010): 271-275; Habtemichael Kidane, "Eucharist," in EAe 2 (2005): 448-45o. 
Church nor conflict with faith."51 The Wittenberg Reformers expressed their explicit support for this ecumenically oriented ecclesiology. 52

The assertion that the fathers of the Reformation and Ethiopian Orthodox Christians confess essentially the same faith was quite extraordinary in the context of the advancing polarization and enduring theological polemics within Latin Christianity in the 16th century. Even though the shortage of accurate knowledge about each other's theological positions of the respective other and possible misinterpretations caused by the difficulties of communication may have contributed to this Orthodox-Protestant ecumenical understanding, this does not undermine the fact that both parties seem to have been genuinely convinced of their accord. Both Luther and Melanchthon have themselves repeatedly spoken about the encounter with the Ethiopian monk, highlighting the perceived accord in the main issues of faith. For instance, three years after the meeting with Abba Mika'el, on 17th November $1537,{ }^{53}$ Luther stated:

Ante triennium nobiscum hic erat monachus Aethiops, cum quo disputabamus per interpretem, et iste omnibus nostris articulis conclusus dicebat: Ista eta bona creda, id est, fides. ${ }^{54}$

Three years ago, there was an Ethiopian monk with us, with whom we had a discussion through an interpreter. He summed up all our articles [of faith] by saying, "This is a good creda, that is faith [in Italian]". ${ }^{55}$

This statement demonstrates a striking parallelism with a passage from Luther's Wittenberg sermon dating from the same year, in which he spoke of the unity of the true church of Christ, referring to a certain Ethiopian as his example of a fellow believer. ${ }^{56}$ The fact that Luther had repeatedly, and in various

51 "Nam etsi orientalis ecclesia habet aliquas dissimiles ceremonias, ipse quoque iudicat, quod dissimilitudo earum non tollat unitatem ecclesiae nec pugnet cum fide." Scheible, Melanchthons Briefwechsel. Vol. T6, 123-124. Translation-s.P.

52 "Hanc sententiam et nos probamus." Ibid.

53 In the edition of the speeches at table, "17 November 1538 " is given as the date, but this may be an error. Insofar as Luther speaks of the monk visiting him ante triennium ("three years ago"), this statement would have to be from the year 1537 .

54 Martin Luther, D. Martin Luthers Werke. Kritische Gesamtausgabe. Tischreden 1531-1546. Vol. 4, 1538-1540 (Weimar: Hermann Böhlaus Nachfolger, 1916), 152-153. See also: Martin Luther, D. Martin Luthers Werke. Kritische Gesamtausgabe. Tischreden 1531-1546. Vol. 5, 1540-1544 (Weimar: Hermann Böhlaus Nachfolger, 1919), 450-451.

55 Translation-s.P.

56 Martin Luther, D. Martin Luthers Werke. Kritische Gesamtausgabe. Vol. 47, Reihenpredigten aus den Jahren 1537 bis 1540 (Weimar: Hermann Böhlaus Nachfolger, 1912), 235-236. 
contexts, expressed the conviction that he professed the same faith with the Orthodox Ethiopians and belonged together with them to the one true Church of Christ, demonstrates the importance of this idea for his ongoing theological reflection. This conviction touched upon one of the core issues of the ecclesiological self-understanding of the Reformation movement, the question regarding the Protestant understanding of the article of faith declaring the unity of the Church. ${ }^{57}$

\section{Oblivion of the Ethiopian Monk and His Disappearance from the Historiography}

However, why has the theological dialogue between Abba Mika'el and Martin Luther virtually been forgotten? The fate of the letter of recommendation issued by the Wittenberg reformers to the Ethiopian monk, its circulation and reception in the subsequent periods of time, can provide some insights in this regard.

At an early stage, among the first generation of Protestants, this encounter seems to have played a considerable role, since both Luther and Melanchthon had repeatedly referred to it. In the 16th century, this text of the letter of recommendation enjoyed wide dissemination. At least nine manuscripts containing the letter of recommendation for Abba Mika'el—a comparatively high number-have survived. ${ }^{58}$ Especially interesting in this regard is a manuscript

57 Still in the year 1532 Luther had to defend this article of the creed in his epistle to Duke Albrecht of Prussia (1490-1568). Cf. Martin Luther, D. Martin Luthers Werke. Kritische Gesamtausgabe. Vol. 30 (Weimar: Hermann Böhlaus Nachfolger, 1910), $55^{2}$.

$5^{8}$ Bibliothèque nationale de France, Paris, Ms. Coll. Dupuy 796, pagina 702-703 (Heading: "Epistola commendatitia data cuidam Aetiopi. Phil. Melanthon pro Mart. Luthero scripsit"); Bibliothèque Sainte-Geneviève, Paris, Ms. 1458, fol. 224v (Heading: "Epistola commendatitia data cuidam Aetiopi. $\Phi$. M. pro M.L. scripsit”); Forschungsbibliothek Gotha der Universität Erfurt, Ms. Chart. B 1483, fol. $84^{\text {r-v }}$ (Heading: "Epistola commendatitia Martini Lutheri data cuidam Aetiopi, authore Ph. Mel."); Herzog August Bibliothek Wolfenbüttel, Cod. Guelf. 64.4 Extrav., fol. $5^{\mathrm{v}}$ (Heading: "Epistola commendatitia Martini Lutheri data cuidam Aetiopi, authore Philip. Melanch.”); Herzog August Bibliothek Wolfenbüttel, Cod. Guelf. 107 Helmst., fol. $10^{\mathrm{v}}$ (Heading: "Epistola commendadicia M. Lutheri data cuidam Aetiopi"); Herzog August Bibliothek Wolfenbüttel, Cod. Guelf. 214 Gud. Lat. $4^{\circ}$, fol. $16^{\text {r-v }}$ (Heading: "Epistola commendadicia D.M.L. data cuidam Aetiopi"); Stadtbibliothek Trier, Ms. 1880/1444, fol. 135 ${ }^{\mathrm{r}-\mathrm{v}}$ (Heading: "Testimonium datum cuidam Aethiopi a. d. martino Luther"); Universitätsbibliothek Basel, Ms. O III 4, fol. 124 $4^{\mathrm{v}}-125^{\mathrm{r}}$ (Heading: "Epistola commendatitia M. Luth. data cuidam Episcopo”); Universitätsbibliothek Leipzig, Ms. 263o, fol. $6 \mathrm{o}^{\mathrm{r}}-6 \mathrm{1}^{\mathrm{r}}$ (Heading: "Commendatio data Aethiopi Anno 1535"). 
now kept in the Basel University Library. The title of the letter of recommendation "Epistola commendatitia M. Luth. data cuidam Æpiscopo" indicates that Luther had given it to an "Æpiscopo," a bishop..$^{59}$ In the context of the Ethiopian ecclesiastical structure, this anyway remarkable transformation of the status of Abba Mika'el, who was a deacon, had an important implication. Since, until the 2oth century, the Ethiopian Church has merely had one single bishop at any given time, the claim that Luther met an Ethiopian bishop would imply that he met the head of the Ethiopian Orthodox Church.

The letter of recommendation was not only copied by hand, but was published in 1565 , just five years after Melanchthon's death. Johannes Manlius, an alumnus of the Wittenberg University, included the letter of recommendation in the first printed edition of Melanchthon's letters, Epistolarum D. Philippi Melanchthonis Farrago, containing about 35 o letters (about 200 of which have not survived anywhere else). ${ }^{60}$ However, Melanchthon's son-in-law Caspar Peucer reacted furiously to Manlius' publication ${ }^{61}$ and in the same year produced an alternative, much smaller, edition of letters from his father-in-law, Epistolae selectiores aliquot Philippi Melanthonis. ${ }^{62}$ Peucer's edition did not include the letter of recommendation issued for the Ethiopian monk.

In following times, the willingness to commemorate Luther's meeting with an Ethiopian Orthodox theologian gradually declined. The dynamics of oblivion of the Ethiopian monk can be clearly seen in the production of further printed editions of this recommendation letter.

The next time the letter of recommendation was published was two centuries later, in 1784. Gottfried Schütze, the theologian and director of the Hamburg Public Library, had found the text in the holdings of his library and published it in both the Latin original and a German translation. ${ }^{63}$ However, this publication was accompanied by a new attribution of meaning. Insofar as the letter of recommendation, among other things, referred to orientalis ecclesia,

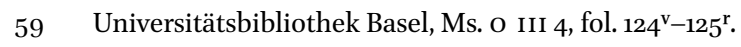

6o Johannes Manlius, ed., Epistolarum D. Philippi Melanchthonis Farrago (Basel: Queck, 1565), 367-368. About Manlius, see: Matthias Simon, "Johann Manlius, der erste Herausgeber von Melanchthonsbriefen," Zeitschrift für Bayerische Kirchengeschichte 24 (1955): 141-149.

61 Christiane Mundhenk, "Briefe," in Philipp Melanchthon. Der Reformator zwischen Glauben und Wissen. Ein Handbuch, ed. Günter Frank (Berlin: de Gruyter, 2017), 316.

62 Caspar Peucer, ed., Epistolae selectiores aliquot Philippi Melanthonis (Wittenberg: Crato, 1565).

63 Gottfried Schütze, ed., D. Martin Luthers bisher ungedruckte Briefe. Vol. 2 (Leipzig: Weygandsche Buchhandlung, 1781), 319-320 and Gottfried Schütze, ed., D. Martin Luthers bisher grossentheils ungedruckte Briefe. Nach der Sammlung des Hrn. D. Gottf. Schütze, aus dem Latein übersetzt. Vol. 2 (Leipzig: Christian Friedrich Wapßler, 1784), 54. 
the Eastern church, and its doctrine, Schütze was led to the mistaken conclusion that this was to be equated with the Greek Church, which was probably the most familiar to him. He introduced the text as follows: "A recommendation letter for a foreigner, who in regard to his confession belonged to the Greek Church, thereby however thought in a fairly good and Protestant way."64

The assertion that Abba Mika'el, who as a clergyman of the Ethiopian Church obviously stood in the miaphysite theological tradition, would have followed the creed of the Greek (i.e. a Chalcedonian) Church, indicates an undifferentiated view of the Christian East. This view was not only left uncorrected in the following publications of the letter of recommendation, but even consolidated. Thus, Wilhelm Martin Leberecht de Wette, professor of Theology at the University of Basel, went even further and transformed the Ethiopian monk into a "Greek clergyman." In his edition of Luther's correspondence published in 1827, he titled the letter of recommendation for $A b b a$ Mika'el as: "Open Letter of Recommendation. L.[uther] recommends a Greek clergyman as being orthodox." ${ }^{65}$ The Ethiopian monk disappeared.

The idea of Luther having amicable theological conversations with an African theologian and advocated the idea that they belonged to the same church did not fit into the emerging nationalistic Luther imaginations of the 18th and 19th centuries. Up until to the 2oth century, the editors found it difficult to see Abba Mika'el as an Ethiopian and provide the letter of recommendation with an appropriate title. Only in a volume of Luther's correspondence, published by the Reformation historian Ludwig Enders in 1903, the text received a suitable heading: "Letter of Recommendation for an Ethiopian, named Michael." 66

This phenomenon can be described as a retrospective confessional standardization of history on the part of the editors. The marginalization of the Ethiopian monk in the historiography took place typically by means of providing misleading titles to the respective texts but was not limited to it. Noteworthy example in this respect offers the handling of the letter of recommendation in the famous Weimar edition of Martin Luther's works. Even though in the accompanying text to the letter of recommendation, the editor had referred

64 "Empfehlungsschreiben für einen Fremdling, der sich in Absicht auf sein Glaubensbekenntniß zur griechischen Kirche bekannte, aber doch dabey recht gut und evangelisch dachte." Ibid.

65 Wilhelm Martin Leberecht de Wette, ed., Dr. Martin Luthers Briefe, Sendschreiben und Bedenken, vollständig aus den verschiedenen Ausgaben seiner Werke und Briefe, aus andern Büchern und noch unbenutzten Handschriften gesammelt, kritisch und historisch bearbeitet (Berlin: G. Reimer, 1827), 550.

66 Ludwig Enders, ed., Dr. Martin Luther's Briefwechsel. Briefe vom Februar 1534 bis Juli 1536. Vol. 10 (Frankfurt am Main: Schriften-Niederlage des Evangel. Vereins, 19०3), 6o. 
to Abba Mika'el as an Ethiopian, in contrast to other texts in this volume, this letter was not assigned with a sequence number and was not even included in the table of contents. ${ }^{67}$ The disregard of this historical document, which made its reception even more difficult, expressed itself not least in the lack of translations. Since the publication of the first translation into German in 1784 (that has never been reprinted since), no new translations into any modern language has appeared until recently.

The treatment of the letter of recommendation reveals the mechanisms of marginalization to which the memory of Martin Luther's encounter with Abba Mika'el and their ecumenical understanding had been exposed over the last two and a half centuries. Ultimately, these mechanisms unfolded in the longue durée and led to the erasure of the Ethiopian monk's visit to Wittenberg from the archives of collective memory. A critical examination of this process not only exposes mechanisms of confessional memory, but also shows how fragile these constructed self-images are. Ironically, the effort of Lutherans over the last two and a half centuries to not remember the meeting of the Wittenberg reformers with Abba Mika'el stands in contrast to the recollection of this event by Luther, who had himself repeatedly reffered to it. Nevertheless, the fact that Luther's theological dialogue with the Ethiopian monk still largely remains forgotten shows how powerful the mechanisms of retrospective confessional standardization of history actually are.

The travel of Abba Mika'el to the cradle of the Reformation and his dialogue with the Wittenberg reformers resulted in the mutual discovery of the unity of the Church challenges the perception of the early modern time as a period in the history of Christianity in which processes of globalization were driven exclusively by the Europeans discovering the wider world and expanding their missionary network. Furthermore, the encounter of the Ethiopian monk with Martin Luther exemplifies how global epistemic entanglements shaped the early formation of Protestantism. As long as Protestants found themselves at a formative stage, the reference point of the Ethiopian other played a stabiliz-

67 The letter of recommendation was simply printed between two other letters, Nr. 2126 "Luther an den Rat zu Regensburg. 30. Juni 1534" and Nr. 2127 "Luther an Friedrich Myconius in Gotha, 5. Juli 1534." Martin Luther, D. Martin Luthers Werke. Kritische Gesamtausgabe. Briefwechsel. Vol. 7, 1534-1536 (Weimar: Hof-Buchdruckerei und Verlagsbuchhandlung, 1937), 86. 
ing role. In the context of theological polarization within Roman Christianity, the idea of common belonging to the very same church as Orthodox Christians in distant parts of the world gave credibility to the article of the creed regarding the unity and universality of the church. For Luther, the ecumenical agreement with Abba Mika'el became not least a means of inscribing the Reformation into the global Christian context.

Whereas the study of religious contacts between Europe and the Horn of Africa has so far been predominantly focused on relations between the Ethiopian Orthodoxy and Roman Catholicism, Protestantism was virtually missing in the picture of the Ethiopian-European relations of the 16th century. Conventionally, scholars of Ethiopian studies suggest that the first encounter between Protestantism and Ethiopian Orthodox Christianity occurred in 1636, when Peter Heyling, a Lutheran from Lübeck, reached Ethiopia. ${ }^{68}$ Likewise, it is often taken for granted that Luther neither met Africans nor had trustworthy knowledge about the African continent. ${ }^{69}$ Both these ideas have to be revised in the light of the encounter between Abba Mika'el and the Wittenberg reformers.

Ultimately, the theological dialogue between Abba Mika'el and Martin Luther adds to our understanding of how new and connected forms of worldbuilding between Europe and Africa, as well as between Protestantism and Orthodoxy, were negotiated. By doing so, it enables us to revise radically not

68 Cf. for example Gustav Arén, Evangelical Pioneers in Ethiopia. Origins of the Evangelical Church Mekane Yesus (Stockholm: EFs Förlaget, 1978), 32; Ernst Hammerschmidt, "Die äthiopistischen Studien in Deutschland (von ihren Anfängen bis zur Gegenwart)," Annales d'Éthiopie 6, no. 1 (1965): 255; Donald Crummey, Priests and Politicians: Protestant and Catholic Missions in Orthodox Ethiopia, 1830-1868 (Oxford: Oxford University Press, 1972), 10; David D. Grafton, Piety, Politics, and Power. Lutherans Encountering Islam in the Middle East (Eugene: Pickwick Publications, 2009), 153 .

69 See for example: Kirsten Rüther, "Kannte Luther Afrika? Afrika kennt Luther! Eine Skizze zu Luther im südlichen Afrika," in Luther zwischen den Kulturen. ZeitgenossenschaftWeltwirkung, ed. Hans Medick and Peer Schmidt (Göttingen: Vandenhoeck \& Ruprecht, 2004), 337-372; Tom Joseph Omolo, "Luther in Africa," in The Oxford Handbook of Martin Luther's Theology, ed. Robert Kolb, Irene Dingel and L'ubomír Batka (Oxford: Oxford University Press, 2014), 621-626; Martin Junge, "Global Perspectives on the Reformation," in Global Perspectives on the Reformation: Interactions Between Theology, Politics and Economics, ed. Anne Burghardt and Simone Sinn (Leipzig: Evangelische Verlagsanstalt, 2017), 9-17; Heinrich Bedford-Strohm et al., ed., African Christian Theologies and the Impact of the Reformation. Symposion PIASs Rwanda February 18-23, 2016 (Wien: Lit, 2017); Friederike Nüssel and Hans-Peter Großhans, ed., Lutherische Theologie in außereuropäischen Kontexten. Eine Zusammenschau aus Anlass des 5oo. Reformationsjubiläums (Leipzig: Evangelische Verlagsanstalt, 2017). 
only the picture of African-European interactions in the 16th century, but also that of proto-ecumenical relations in the age of the Reformation.

\section{List of References}

Arén, Gustav. Evangelical Pioneers in Ethiopia. Origins of the Evangelical Church Mekane Yesus. Stockholm: EFs Förlaget, 1978.

Asendorf, Ulrich. Die Theologie Luthers nach seinen Predigten. Göttingen:Vandenhoeck \& Ruprecht, 1988.

Asghedom, Samuel. "Contributo dell'Ospizio di Santo Stefano degli Abissini agli Studi Etiopici in Europa." In IV Congresso Internazionale di Studi Etiopici (Roma, 10-15 April 1972). Vol. 1, 389-404. Roma: Accademia nazionale dei Lincei, 1974.

Bauer, Gisa. "Evangelisch-orthodoxe Religionsgespräche im 16. Jahrhundert." In Zwischen theologischem Dissens und politischer Duldung. Religionsgespräche der Frühen Neuzeit, edited by Irene Dingel, Volker Leppin, and Kathrin Paasch, 43-6o. Göttingen: Vandenhoeck \& Ruprecht, 2018.

Baum, Wilhelm. Die Verwandlungen des Mythos vom Reich des Priesterkönigs Johannes. Rom, Byzanz und die Christen des Orients im Mittelalter. Klagenfurt: Kitab, 1999.

Beckingham, Charles Fraser, and George Wynn Brereton Huntingford, ed. The Prester John of the Indies. A True Relation of the Lands of the Prester John; Being the Narrative of the Portuguese Embassy to Ethiopia in 1520, Written by Father Francisco Alvarez. Vol. I. Cambridge: Cambridge University Press, 1961.

Bedford-Strohm, Heinrich, Tharcisse Gatwa, Traugott Jähnichen, and Elisée Musemakweli, ed. African Christian Theologies and the Impact of the Reformation. Symposion PIASS Rwanda February 18-23, 2016. Wien: Lit, 2017.

Benga, Daniel. David Chytraeus (1530-1600) als Erforscher und Wiederentdecker der Ostkirchen. Seine Beziehungen zu orthodoxen Theologen, seine Erforschungen der Ostkirchen und seine ostkirchlichen Kenntnisse. Giessen: VvB Laufersweiler Verlag, 2012.

Benga, Daniel. "Philipp Melanchthon und der christliche Osten. Bis heute unbekannte Begegnungen Melanchthons aus den Jahren 1541 und 1556 mit orthodoxen Christen." Orthodoxes Forum 16 (2002): 19-38.

Benz, Ernst. "Die östliche Orthodoxie und das kirchliche Selbstbewußtsein der Reformation." In Evangelisches und orthodoxes Christentum in Begegnung und Auseinandersetzung, edited by Ernst Benz and Lev Zander, 101-160. Hamburg: Agentur des Rauhen Hauses, 1952.

Benz, Ernst. Wittenberg und Byzanz. Zur Begegnung und Auseinandersetzung der Reformation und der Östlich-orthodoxen Kirche. München: Fink, 1971.

Beylot, Robert. "Le millénarisme, article de foi dans l'Église Éthiopienne au xvme siècle." Rassegna di Studi Etiopici 25 (1971): 31-43. 
Bottschafft des groszmechtigsten Konigs David aus dem grossen und hohen Morenland den man gemeinlich nennet Priester Johann an Babst Clemens den siebenden zu Bononia vorhort in offnem consistorio am XXIX. Tag Januarii Anno M.D.XXXIII. Dresden: Wolfgang Stöckel, 1533 .

Bottschafft des groszmechtigsten Konigs David aus dem grossen und hohen Morenland den man gemeinlich nennet Priester Johann an Babst Clemens den siebenden zu Bononia vorhort in offnem consistorio am XXIX. Tag Januarii Anno M.D.XXXIII. Nürnberg: Friedrich Peypus, 1533 .

Brecht, Martin. Martin Luther. Vol. 3, Die Erhaltung der Kirche:1532-1546. Stuttgart: Calwer, 1987.

Bretschneider, Carolus Gottlieb, ed. Philippi Melanthonis Opera Quae Supersunt Omnia. Vol. 2. Halis Saxonum: C.A. Schwetschke et Filium, 1835.

Cerulli, Enrico. Scritti teologici etiopici dei secoliXVI-XVII. Vol. 1, Tre opuscoli dei Mikaeliti. Città del Vaticano: Bibl. Apostolica Vaticana, 1958.

Chaîne, Marius. "Un monastère éthiopien à Rome au Xve et Xvie siècle." Mélanges de la Faculté Orientale, Bayreuth 5 (1911): 1-36.

Cohen, Leonardo. The Missionary Strategies of the Jesuits in Ethiopia (1555-1632). Wiesbaden: Harrassowitz, 20o9.

Conti Rossini, Carlo, and Lanfranco Ricci, ed. Il Libro Della Luce del Negus Zar'a Yā́qob (Mașhafa Berhān). Vol. 2. Louvain: Peeters, 1965.

Crummey, Donald. Priests and Politicians: Protestant and Catholic Missions in Orthodox Ethiopia, 1830-1868. Oxford: Oxford University Press, 1972.

Daniels, David. "Luther and Ethiopian Christianity." In Reformation in the Context of World Christianity. Theological, Political and Social Interactions Between Africa, Asia, the Americas and Europe, edited by Frieder Ludwig, Wilhelm Richebächer, Mirjam Laaser, Amélé Ekué, and Pui-Yee Pong, 21-31. Wiesbaden: Harrassowitz, 2019.

Daniels III, David, and Lawrence Anglin. "Luther and the Ethiopian Deacon." Lutheran Quarterly 32 (2018): 428-434.

Dannenfeldt, Karl. "Leonhard Rauwolf: A Lutheran Pilgrim in Jerusalem, 1575." Archiv für Reformationsgeschichte 55, no. 1 (1964): 18-36.

De Lorenzi, James. "Red Sea Travelers in Mediterranean Lands: Ethiopian Scholars and Early Modern Orientalism, ca. 1500-1668." In World-Building and the Early Modern Imagination, edited by Allison B. Kavey, 173-200. New York: Palgrave Macmillan, 2010.

Dingel, Irene, ed. Die Bekenntnisschriften der Evangelisch-lutherischen Kirche. Vollständige Neuedition. Göttingen: Vandenhoeck \& Ruprecht, 2014.

Döpmann, Hans-Dieter. "Das Verhältnis Luthers und der Lutheraner zu den orthodoxen Kirchen." Theologische Literaturzeitung 109, no. 5 (1984): 321-334.

Enders, Ludwig, ed. Dr. Martin Luther's Briefwechsel. Briefe vom Februar 1534 bis Juli 1536. Vol. 1o. Frankfurt am Main: Schriften-Niederlage des Evangel. Vereins, $19 \circ 3$. 
Euringer, Sebastian. "San Stefano dei Mori (Vatikanstadt) in seiner Bedeutung für die abessinische Sprachwissenschaft und Missionsgeschichte." Oriens Christianus $3^{2}$, no. 3 (1935): $38-59$.

Fiaccadori, Gianfranco. “Venezia, l'Etiopia el'Europa." In "Nigra sum sed formosa." Sacro e bellezza dell'Etiopia cristiana (13 Marzo-10 Maggio 2009), edited by Giuseppe Barbieri and Gianfranco Fiaccadori, 27-48. Crocetta del Montello: Terra ferma, 2009.

Fiaccadori, Gianfranco. “Prester John." In EAe 4 (2010): 209-216.

Fiaccadori, Gianfranco. "Santo Stefano dei Mori." In EAe 4 (2010): 528-532.

Fritsch, Emmanuel. “Qəddase.” In EAe 4 (2010): 271-275.

Getatchew Haile. "Ethiopian Orthodox (Täwaḩədo) Church. History from Ancient Times till the Second Half of the 19th Century." In EAe 2 (2005): 414-421.

Getatchew Haile. "Religious Controversies and the Growth of Ethiopic Literature in the Fourteenth and Fifteenth Centuries." Oriens Christianus 65 (1981): 102-136.

Getatchew Haile. "The Homily of Zär’a Ya`əqob in Honour of St. John the Evangelist, EMML 1480, ff. $48^{\mathrm{r}}-5^{2}$ v". Oriens Christianus 67 (1983): 144-166.

Getatchew Haile. “Zämika'elites." In EAe 5 (2014): 131-133.

Góis, Damião de. Legatio magni Indorum Imperatoris Presbyteri Ioannis, ad Emanuelem Lusitaniae Regem, Anno Domini. M.D. XIII. Antwerpen: Grapheus, 1532.

Góis, Damião de. Fides, Religio, Moresque Aethiopum: sub imperio Preciosi Johannis degentium una cum enarratione confoederationis ac amicitiae inter ipsos Aethiopum imperatores et reges Lusitaniae initae [...]. Lovanii: Ex officina Rutgeri Rescij, 1540.

Grafton, David D. Piety, Politics, and Power. Lutherans Encountering Islam in the Middle East. Eugene: Pickwick Publications, 2009.

Grébaut, Sylvain. "Contribution à l'histoire du couvent éthiopien San-Stefano-deiMori." Revue de l'Orient chrétien 26, no. 3 (1927): 211-218.

Grébaut, Sylvain. "La règle de Santo Stefano dei Mori." Revue de l'Orient chrétien 27, no. 3 (1929): 214-219.

Grébaut, Sylvain, and Eugène Tisserant. Bybliothecae apostolicae Vaticanae codices manu scripti recensiti iussu Pii XI Pontificis maximi. Città del Vaticano: Bybliotheca Vaticana, 1935 .

Gumilev, Lew. Searches for an Imaginary Kingdom. The Legend of the Kingdom of Prester John. Cambridge: Cambridge University Press, 1987.

Habtemichael Kidane. "Eucharist." In EAe 2 (2005): 448-45o.

Habtemichael Kidane. "Səbhätä Fəqur." In EAe 4 (2010): 589-59o.

Hall, Ashley H. Philip Melanchthon and the Cappadocians. A Reception of Greek Patristic Sources in the Sixteenth Century. Göttingen: Vandenhoeck \& Ruprecht, 2014.

Hammerschmidt, Ernst. "Die äthiopistischen Studien in Deutschland (von ihren Anfängen bis zur Gegenwart)." Annales d'Éthiopie 6, no. 1 (1965): 255-277.

Hardt, Tom G.A. "The Confessional Principle. Church Fellowship in the Ancient and in the Lutheran Church." Logia. A Journal of Lutheran Theology VIII, no. 2 (1999): 21-3o. 
Hein, Martin. "Das Schicksal des Franz Magera. Ein Beitrag zum Verhältnis von Reformation und Türkenkriegen." Archiv für Reformationsgeschichte 73 (1982): 308-313.

Heldman, Marilyn E. “Trinity in Art.” In EAe 4 (2010): 994-996.

Hering, Gunnar. "Orthodoxie und Protestantismus." In Jahrbuch der Österreichischen Byzantinistik 31, no. 2, edited by Herbert Hunger, 823-874. Wien: Verlag der Österreichischen Akademie der Wissenschaften, 1981.

Heyer, Friedrich. Die Kirche Äthiopiens. Eine Bestandsaufnahme. Berlin: Walter de Gruyter, 1971.

Hoffmann, Gottfried. Kirchenväterzitate in der Abendmahlskontroverse zwischen Oekolampad, Zwingli, Luther und Melanchton: Legitimationsstrategien in der inner-reformatorischen Auseinandersetzung um das Herrenmahl. Göttingen: Edition Ruprecht, 2011.

Jansen, Reiner. Studien zu Luthers Trinitätslehre. Bern: Lang, 1976.

Junge, Martin. "Global Perspectives on the Reformation." In Global Perspectives on the Reformation: Interactions Between Theology, Politics and Economics, edited by Anne Burghardt and Simone Sinn, 9-17. Leipzig: Evangelische Verlagsanstalt, 2017.

Kaplan, Steven, and Marie-Laure Derat. "Zär’a Ya`əqob." In EAe 5 (2014): 146-150.

Karmiris, Johannes. "Luther und Melanchthon über die Orthodoxe Kirche (I)." Kyrios 6, no. 2 (1966): 77-104.

Karmiris, Johannes. "Luther und Melanchthon über die Orthodoxe Kirche (II)." Kyrios 6 , no. 3 (1966): 150-173.

Kelly, Samantha, and Denis Nosnitsin. "The Two Yoḥannəses of Santo Stefano degli Abissini, Rome: Reconstructing Biography and Cross-Cultural Encounter Through Manuscript Evidence." Manuscript Studies: A Journal of the Schoenberg Institute for Manuscript Studies 2, no. 2 (2017): 392-426.

Kelly, Samatha. "Medieval Ethiopian Diasporas." In A Companion to Medieval Ethiopia and Eritrea, edited by Samatha Kelly, 425-453. Leiden: Brill, 2020.

Kitromilides, Paschalis. "Orthodoxy and the West. Reformation to Enlightenment." In The Cambridge History of Christianity. Vol. 5, Eastern Christianity, edited by Michael Angold, 187-209. Cambridge: Cambridge University Press, 2006.

Lilienfeld, Fairy von. "Zum Wesen der Kirche. Einheit, Kontinuität und Universalität der heiligen katholischen und apostolischen Kirche in der Theologie Martin Luthers und in der 'eucharistischen Ekklesiologie' des 2o. Jahrhunderts.” In SophiaDie Weisheit Gottes. Gesammelte Aufsätze 1983-1995, edited by Karl Christian Felmy, Heinz Ohme and Karin Wildt, 1-21. Erlangen: Lehrstuhl für Geschichte und Theologie des christlichen Ostens, 1997.

Luther, Martin. D. Martin Luthers Werke. Kritische Gesamtausgabe. Vol. 6, Schriften 1519/20 (einschließlich Predigten, Disputationen). Weimar: Hermann Böhlau, 1888.

Luther, Martin. D. Martin Luthers Werke. Kritische Gesamtausgabe. Vol. 26, Vorlesung über 1. Timotheus 1528; Schriften 1528. Weimar: Hermann Böhlaus Nachfolger, 1909. 
Luther, Martin. D. Martin Luthers Werke. Kritische Gesamtausgabe. Vol. 3o. Weimar: Hermann Böhlaus Nachfolger, 1910.

Luther, Martin. D. Martin Luthers Werke. Kritische Gesamtausgabe. Vol. 37, Predigten der Jahre 1533 und 1534. Weimar: Hermann Böhlaus Nachfolger, 1910.

Luther, Martin. D. Martin Luthers Werke. Kritische Gesamtausgabe. Werke. Vol. 38, Schriften 1533/36. Weimar: Hermann Böhlaus Nachfolger, 1912.

Luther, Martin. D. Martin Luthers Werke. Kritische Gesamtausgabe. Vol. 41, Predigten der Jahre 1535 und 1536. Weimar: Hermann Böhlaus Nachfolger, 1910.

Luther, Martin. D. Martin Luthers Werke. Kritische Gesamtausgabe. Vol. 47, Reihenpredigten aus den Jahren 1537 bis 1540. Weimar: Hermann Böhlaus Nachfolger, 1912.

Luther, Martin. D. Martin Luthers Werke. Kritische Gesamtausgabe. Vol. 59, Nachträge zu Band 1-57 und zu den Abteilungen "Deutsche Bibel" und "Tischreden." Weimar: Hermann Böhlaus Nachfolger, 1983.

Luther, Martin. D. Martin Luthers Werke. Kritische Gesamtausgabe. Tischreden 1531-1546. Vol. 4, 1538-1540. Weimar: Hermann Böhlaus Nachfolger, 1916.

Luther, Martin. D. Martin Luthers Werke. Kritische Gesamtausgabe. Tischreden 1531-1546. Vol. 5, 1540-1544.Weimar: Hermann Böhlaus Nachfolger, 1919.

Luther, Martin. D. Martin Luthers Werke. Kritische Gesamtausgabe. Briefwechsel. Vol. 7, 1534-1536. Weimar: Hof-Buchdruckerei und Verlagsbuchhandlung, 1937.

Manlius, Johannes, ed. Epistolarum D. Philippi Melanchthonis Farrago. Basel: Queck, 1565 .

Markschies, Christoph. "Luther und die altkirchliche Trinitätstheologie." In Lutherzwischen den Zeiten. Eine Jenar Ringvorlesung, edited by Christoph Markschies and Michael Trowitzsch, 37-85. Tübingen: Mohr Siebeck, 1999.

Martikainen, Jouko. "Christologische und trinitätstheologische Aporien der östlichen Kirche aus der Sicht Luthers." In Luther und die trinitarische Tradition: Ökumenische und Philosophische Perspektiven, edited by Joachim Heubach, 71-94. Erlangen: Martin-Luther-Verlag, 1994.

Mauro da Leonessa. Santo Stefano Maggiore degli Abissini e le relazioni romano-etiopiche. Vatican: Tipografia Poliglota Vaticana, 1928.

Mebratu Kiros Gebru. Liturgical Cosmology. The Theological and Sacramental Dimensions of Creation in the Ethiopian Liturgy. Ph.D. Dissertation, University of Toronto, 2012.

Mehedintu, Viorel. "Martin Luther und die Ostkirche." Ökumenische Rundschau 32 (1983): 291-309.

Mundhenk, Christiane. "Briefe." In Philipp Melanchthon. Der Reformator zwischen Glauben und Wissen. Ein Handbuch, edited by Günter Frank, 303-319. Berlin: de Gruyter, 2017 .

Nikolaou, Theodor. "Die orthodox-lutherischen Beziehungen im 16. Jahrhundert." Ökumenische Information 14/15 (1980): 7-10. 
Nüssel, Friederike, and Hans-Peter Großhans, ed. Lutherische Theologie in außereuropäischen Kontexten. Eine Zusammenschau aus Anlass des 500. Reformationsjubiläums. Leipzig: Evangelische Verlagsanstalt, 2017.

Oberdorfer, Bernd. Filioque. Geschichte und Theologie eines ökumenischen Problems. Göttingen: Vandenhoeck \& Ruprecht, 2001.

Omolo, Tom Joseph. "Luther in Africa." In The Oxford Handbook of Martin Luther's Theology, edited by Robert Kolb, Irene Dingel, and L'ubomír Batka, 621-626. Oxford: Oxford University Press, 2014.

Paulau, Stanislau. Das andere Christentum. Zur transkonfessionellen Verflechtungsgeschichte von äthiopischer Orthodoxie und europäischem Protestantismus. Göttingen: Vandenhoeck \& Ruprecht, 2021. Dor: https://doi.org/10.13109/9783666336041.

Paulau, Stanislau. "Re-Envisioning Ecumenism and World Christianity in the Age of Reformation: The Theological Dialogue of Abba Mika'el and Martin Luther." Ecumenical Trends 50, no. 3 (2021): 2-5.

Păvălucă, Vasilică Mugurel. "Einige schriftliche Verweise Martin Luthers auf die Ostkirche." Review of Ecumenical Studies Sibiu 9, no. 3 (2017): 36o-37o.

Peucer, Caspar, ed. Epistolae selectiores aliquot Philippi Melanthonis. Wittenberg: Crato, 1565 .

Piovanelli, Pierluigi. "Connaissance de Dieu et sagesse humaine en Éthiopie. Le traité Explication de la Divinité attribué aux hérétiques 'mikaélites'” Muséon 117 (2004): 193-227.

Piovanelli, Pierluigi. "Les controverses théologiques sous le roi Zar’a Yā‘əqob (14341468) et la mise en place du monophysisme éthiopien." In La controverse religieuse et ses formes, edited by Alain Le Boulluec, 189-228. Paris: Cerf, 1995.

Plajer, Dietmar. "Auftrag und Grenzen. Zu den Anfängen lutherisch-orthodoxer Beziehungen im 16. Jahrhundert." Review of Ecumenical Studies Sibiu 10, no. 1 (2018): 90103 .

Pósfay, George. “'The Whole Christian Church on Earth'-Luther's Conception of the Universality of the Church." Lutheran Theological Seminary (Gettysburg) Bulletin 72 (1992): 20-43.

Rauwolf, Leonhard. Aigentliche beschreibung der Raiß, so er vor diser Zeit gegen Auffgang inn die Morgenländer, fürnemlich Syriam, Judaeam, Arabiam, Mesopotamiam, Babyloniam, Assyriam, Armeniam selbs volbracht. Augsburg: Willer, 1583 .

Rüther, Kirsten. "Kannte Luther Afrika? Afrika kennt Luther! Eine Skizze zu Luther im südlichen Afrika." In Luther zwischen den Kulturen. Zeitgenossenschaft-Weltwirkung, edited by Hans Medick, and Peer Schmidt, 337-372. Göttingen: Vandenhoeck \& Ruprecht, 2004.

Salvadore, Matteo. The African Prester John and the Birth of Ethiopian-European Relations, 1402-1555. London: Routledge, Taylor \& Francis Group, 2017.

Salvadore, Matteo. "The Ethiopian Age of Exploration: Prester John's Discovery of Europe, 1306-1458." Journal of World History 21, no. 4 (2011): 593-627. 
Scheible, Heinz, ed. Melanchthons Briefwechsel. Kritische und kommentierte Gesamtausgabe. Vol. 10, Orte A-Z und Itinerar. Stuttgart-Bad Cannstatt: frommann-holzboog, 1998.

Scheible, Heinz, ed. Melanchthons Briefwechsel. Kritische und kommentierte Gesamtausgabe. Vol. T6, Texte 1395-1683 (1534-1535). Stuttgart-Bad Cannstatt: frommannholzboog, 2005 .

Schütze, Gottfried, ed. D. Martin Luthers bisher ungedruckte Briefe. Vol. 2. Leipzig: Weygandsche Buchhandlung, 1781.

Schütze, Gottfried, ed. D. Martin Luthers bisher grossentheils ungedruckte Briefe. Nach der Sammlung des Hrn. D. Gottf. Schütze, aus dem Latein übersetzt. Vol. 2. Leipzig: Christian Friedrich Wapßler, 1784.

Simon, Matthias. "Johann Manlius, der erste Herausgeber von Melanchthonsbriefen." Zeitschrift für Bayerische Kirchengeschichte 24 (1955): 141-149.

Slenczka, Reinhard. "Melanchthon und die orthodoxe Kirche des Ostens." In Philipp Melanchthon. Ein Wegbereiter für die Ökumene, edited by Jörg Haustein, 98-119. Göttingen: Vandenhoeck \& Ruprecht, 1997.

Tedros Abraha. “Trinity." In EAe 4 (2010): 990-994.

Trimingham, John Spencer. Islam in Ethiopia. London: Routledge, 2008.

Uhlig, Siegbert, and Gernot Bühring, ed. Damian de Góis'Schrift über Glaube und Sitten der Äthiopier Wiesbaden: Harrassowitz, 1994.

Wagner, Oskar. "Luther-Osteuropa und die griechisch-orthodoxe Kirche." Kyrios 4 (1964): 69-9o.

Wendebourg, Dorothea. Reformation und Orthodoxie. Der ökumenische Briefwechsel zwischen der Leitung der Württembergischen Kirche und Patriarch Jeremias II. von Konstantinopel in den Jahren 1573-1581. Göttingen: Vandenhoeck \& Ruprecht, 1986.

Wendt, Kurt, ed. Das Maṣhafa Milād (Liber Nativitatis) und Maṣhafa Sellāsē (Liber Trinitatis) des Kaisers Zar'a Yã́qob. [Vol. Versio 1]. Louvain: Peeters, 1963.

Wendt, Kurt. "Die theologischen Auseinandersetzungen in der äthiopischen Kirche zur Zeit der Reformen des Xv. Jahrhunderts." In Atti del Convegno Internazionale di Studi Etiopici (Roma 2-4 Aprile 1959), 137-146. Roma: Accad. nazionale dei Lincei, 196o.

Wengert, Timothy J. “Melanchthon's First Letter about an Ethiopian Visitor to Luther's Wittenberg." Lutheran Quarterly 35 (2021): 182-188.

de Wette, Wilhelm Martin Leberecht, ed. Dr. Martin Luthers Briefe, Sendschreiben und Bedenken, vollständig aus den verschiedenen Ausgaben seiner Werke und Briefe, aus andern Büchern und noch unbenutzten Handschriften gesammelt, kritisch und historisch bearbeitet. Berlin: G. Reimer, 1827. 